\title{
Influence of Grapevine Leafroll-associated Virus-3 in Mature Plants of Vitis vinifera L. cv Albariño on 110R and 196.17C Rootstocks
}

\author{
C. Cabaleiro, * A.M. Pesqueira, J.J. García-Berrios \\ Universidade de Santiago de Compostela, Escola Politécnica Superior de Enxeñaría, Campus Terra, 27002, Lugo, Spain
}

Submitted for publication: March 2021

Accepted for publication: July 2021

Key words : Grapevine leafroll disease, GLRaV-3, rootstocks, 110R, 196.17C, yield, Brix, PAN, ammonium

\begin{abstract}
The detrimental effects of grapevine leafroll disease (GLD) have been documented mainly in young plants and little data is available on infected grapevines when they reach maturity. This study examined the influence of the rootstock on the effect of GLRaV-3 in a 20-year-old Vitis vinifera cv Albariño vineyard in which the virus has been spread by Planococcus ficus. Plants grafted on Richter 110 or Castell 196.17 with similar development were analysed for grapevine leafroll-associated viruses. In particular, 25 GLRaV-3infected and 25 leafroll-free and asymptomatic vines were selected and monitored during a period of three years to determine grape yield and must components. Although the virus infection affected plants on both rootstocks, it caused a greater effect on plants grafted onto 110R, with average accumulated yield losses of up to $33 \%$, relative to losses of $16 \%$ for plants on $196.17 \mathrm{C}$. The sugar content was lower in the must from infected plants on $110 \mathrm{R}\left(-2.1^{\circ} \mathrm{Brix}\right)$ than in the must from plants on $196.17 \mathrm{C}\left(-1.5^{\circ} \mathrm{Brix}\right)$. The presence of the virus was associated with decreased concentrations of primary amino nitrogen (PAN) and ammonium $\left(\mathrm{NH}^{+}\right)$, with the greatest effect for $110 \mathrm{R}(-35 \%)$. As $110 \mathrm{R}$ is the most used rootstock in Spain, particular care must be taken to prevent the transmission of GLRaV-3 to certified virus-free plants on 110R in new vineyards. In sensitive varieties such as Albariño, particularly in areas with an active spread of the virus by mealybugs, grafting on 196.17C seems to minimise the effect that GLD has in a medium to long term.
\end{abstract}

\section{INTRODUCTION}

Grapevine leafroll disease (GLD) is the most widespread viral disease of grapevines, and several studies have been conducted in the past decade that highlight the economic effect of this disease (Freeborough \& Burger, 2008; Atallah et al., 2012; Cabaleiro et al., 2013; Ricketts et al., 2015; Fuller et al., 2019; Bell et al., 2021). Among members of the family Closteroviridae associated with GLD, the ampelovirus Grapevine leafroll associated virus 3 (GLRaV-3) is the most prevalent, with proven detrimental effects on grapevine growth, vigour, yield and fruit quality (Charles et al., 2006; Maree et al., 2013; Naidu et al., 2014, 2015). The GLD typically causes rolling and interveinal reddening (red fruit cultivars) or yellowing (white cultivars) of mature leaves in the late summer. However, the performance of infected plants and the severity of the disease are affected by multiple factors, such as virus species and variants, grapevine cultivar, timing of infection, trellis system, management and environmental conditions (Almeida et al., 2013). The expression of symptoms differs among Vitis vinifera cultivars when they are grown on their own roots (Krake, 1993; Pesqueira et al., 2018). In addition, some findings suggest that, for the same cultivar, the detrimental effects of GLD may be related to the rootstock (Almeida et al., 2013).
Phylloxera-resistant rootstocks have been selected based on how they adapt to the prevalent soil conditions in most grape-growing regions in Mediterranean climates. Other objectives of rootstock selection are related to yield management and grape quality, i.e. fruit set, plant vigour, early or late ripening (Dry, 2007) and resistance to soil pathogens such as nematodes. Resistance to GLD has not been taken into account because most rootstocks are considered resistant because they do not show any symptoms of the disease, and the virus seems to replicate more slowly, making detection more difficult (Cid et al., 2003).

Uyemoto et al. (2001) reported a closterovirus that causes the decline of grafted plants or union incompatibility on sensitive rootstocks. Among the leafroll viruses, only the closterovirus GLRaV-2 has been associated with graft incompatibility (Greif et al., 1995; Borgo et al., 2006). However, for many cultivar/rootstock combinations, GLRaV-2 alone usually induces only mild symptoms (García-Berrios et al., 2007; Pesqueira et al., 2009; Volpe et al., 2010).

In the early 1990s, stunted growth and death of young vines were observed in newly planted vineyards in California as a result of changes in the choice of rootstock

*Corresponding author: cristina.cabaleiro@usc.es

Acknowledgements: Financial support for this study was provided by CDTI-2017-CE074. We want to thank Pablo Bóveda, for his assistance with the must analysis, Paula Caballero, for her help during harvest, and Christine Francis, for her revision of the language 
used and the presence of infected material. These symptoms were eventually associated with a disease called "virusinduced rootstock decline" (VIRD), which is mainly caused by co-infection with GVB and GLRaV-2 (Golino, 1993; Golino et al., 2000, 2003). The effect of GLRaVs on grapevines grafted on Freedom and Harmony rootstocks was considerable, in contrast to those grafted on AxR, which remained asymptomatic (Golino et al., 2003).

In a more recent study conducted in California, the interaction between some leafroll viruses and rootstocks was shown to have a clear effect on vine development. In conclusion, a preliminary classification of sensitivity to GLRaVs and vitivirus was established in relation to the rootstock: 5BB was affected the most, followed by 3309C, Freedom, 110R, St. George 18, St. George 15, AXR.1, 101.14 and 420A (Golino et al., 2008; Rowhani et al., 2015). In a sixyear-long study of the effects of a combination of GLRaV-1 and several other grapevine viruses on Vitis rupestris, Kober 5BB and 161-49 Couderc rootstocks, Komar et al. (2010) did not detect any interactions.

The "Albariño" white grape is the most widely cultivar grown in the Rías Baixas appellation. However, vineyards of this cultivar did not become commercially important until the end of the $20^{\text {th }}$ century. A limited number of more than 100-year-old, own-rooted Albariño vines have been used as the source of grafts for new vineyards since the 1970s, and about $30 \%$ of these plants were infected with leafroll viruses (serological analysis confirmed by indexing). The most common rootstock for Albariño is 196.17C, owing to its allegedly better performance in the acid soils that predominate in Galicia. The effect of leafroll disease on the performance of Albariño vineyards between the 1990s and the 2000s has been evaluated (Cabaleiro \& Segura, 1996; Cabaleiro et al., 1999; García-Berrios et al., 2007). All of the information available about the effect of the disease, along with the prices and penalties applied by wineries according to the sugar content of the must, was used to estimate current and future economic losses (Cabaleiro et al., 2013). The study was focused mainly on data on must sugar content, as this was the main problem detected in the three vineyards studied. But the yield was also significantly lower in one mature vineyard grafted on 110R (Cabaleiro \& Segura, 1996); in that vineyard, the gradual decrease in grape production, together with failure to reach the desirable sugar content, shortened its lifespan. Field monitoring of the red cultivar Mencía in several inland vineyards in Galicia also revealed important reductions in the yield of GLRaV3 -infected plants when grafted on 110R (Pesqueira et al., 2009).

A tendency towards lower production and delayed harvesting date was detected in the historical records from a commercial vineyard in the south of Galicia in which the plantations were established between 1990 and 2000. In response to these findings, the owners uprooted and replanted several plots ahead of schedule (vines younger than 30 years). The main rootstock used in this vineyard was 110R, although 196.17C was used as an alternative in some areas. This study aims to compare mature Albariño plants grafted onto both rootstocks in order to determine whether the $110 \mathrm{R}$ rootstock exacerbates the effect of GLD in Albariño plants.

\section{MATERIALS AND METHODS}

\section{Vineyard}

Two areas within a commercial vineyard in "O Rosal" (Pontevedra, Spain) were selected for the study. They were planted in 2000 with the standard plant material of the Albariño cultivar available at the time and have been in full production since 2005 . The vines are grown on a horizontal trellis of $2 \mathrm{~m}$ in height, with two plants per pole and an average of 1500 plants $\cdot$ ha $^{-1}$. The main difference between the selected zones in the vineyard is the rootstock (196.17 Castel or 110 Richter), and all other conditions and management actions are the same in both. The vine mealybug Planococcus ficus Signoret (Hemiptera: pseudococcidae) was quite widespread in the vineyard and has undoubtedly been responsible for the high incidence of GLRaV-3; that was a problem in the selection of leafroll-free plants in as homogeneous an area as possible. The infestation was brought under control by mating disruption and spirotetramat, beginning in 2016.

Meteorological data were retrieved from the automatic weather station (iMetos) in the vineyard. The cumulative growing degree-days from April to October (Winkler Index) were 1 679.4, 1642 and 1505.5 respectively (Region II).

\section{Virus detection and plant selection}

In the late summer of 2016, several rows of plants in each plot were examined for symptoms of leafroll disease and the absence of symptoms of nepoviruses and other diseases (i.e. esca and other trunk diseases). More than 200 plants per rootstock, with similar vigour, were selected, and two mature leaves per plant were collected for analysis by a tissue print ELISA (enzyme-linked immunosorbent assay) to detect the presence of GLRaV-3, as previously described (Cabaleiro et al., 2008). Buffers and alkaline phosphataseconjugated antibodies specific for GLRaVs used in the ELISA were obtained from BIOREBA AG (Switzerland). The nitrocellulose membranes of $0.45 \mu \mathrm{m}$ Sartorius $^{\mathrm{TM}}$ and BCIP-NBT ready-to-use alkaline phosphatase substrate came from Sigma (B1911). The ideal selection of plants in a younger plot would be pairing infected with non-infected at the same pole, or as close as possible, to minimise other effects along the vineyard block. We tried to select healthy and infected plants that were as close as possible, but in an old plot an infected plant close to ones that are not infected often indicates recent transmission, which could be associated with mild or unclear GLD symptoms. Our priority in late summer 2016 was the selection of plants with typical symptoms of GLD, which again were clear at harvest in 2017. The plants selected as positive and negative for GLRaV-3 were also analysed for GLRaV-1 and 2 to avoid including plants with mixed infections of the most common leafroll viruses, or asymptomatic plants negative for GLRaV-3 but with GLRaV-2, which does not give clear GLD symptoms in Albariño (García-Berrios et al., 2007). Those viruses were not detected and we selected 25 positive and symptomatic and 25 negative and symptomless plants for each rootstock. Grapevines without GLD symptoms were retested by DIP-ELISA in each season. In 2019, some plants did not have enough bunches to analyse due to environmental conditions during fruit set, and we had to work with 10 to 15 plants per virus status and rootstock. All vines were 
examined for severity of GLD symptoms at harvest in 2017, 2018 and 2019.

\section{Data recorded}

During 2017, 2018 and 2019, the following samples/data were obtained/recorded:

\section{GLD symptoms}

At harvest, each plant was observed for symptoms of GLD, that is leaf rolling with or without yellowing, with main veins remaining green, and abnormal texture. These were registered using a descriptive scale of 0 to 3 that considered severity and area affected, with $0=$ no symptoms, $1=$ mild symptoms in a few old leaves, 2 = clear leafroll symptoms but not generalised, and 3 = clear leafroll symptoms in most old leaves. A disease severity index (DSI) was calculated for the infected plants: $\{$ sum(class frequency x score of rating class) $\} /$ (total number of plants).

\section{Production}

The weight of 10 clusters picked randomly from all branches of each plant was used to calculate the average cluster weight $(\mathrm{CW})(\mathrm{g})$; the total production was weighed to obtain the yield per plant $(\mathrm{kg})$.

\section{Must analysis}

The must from the 10 clusters from each plant was extracted by crushing the bunches in large basins the morning after the harvest; a sample $(100 \mathrm{~mL})$ was obtained and filtered prior to analysis. The following analyses were done on the fresh must samples: total soluble solids (TSS) ( ${ }^{\circ}$ Brix), using a handheld refractometer; total titratable acidity (TA) $\left(\mathrm{g} \cdot \mathrm{L}^{-1}\right.$ tartaric acid), by titration with $0.1 \mathrm{~N} \mathrm{NaOH}$; and $\mathrm{pH}$, measured with a pH meter (Eutech Instruments Europe BW, Netherlands). Some additional determinations were conducted with a BioSystems Autoanalyzer A-25; the program, reagents and standards were provided by BioSystems. All the must samples were stored frozen at $-50^{\circ} \mathrm{C}$ prior to analysis. The analytical methods are compatible with the methods proposed by the International Vine and Wine Organization (OIV): malic acid $\left(\mathrm{g} \cdot \mathrm{L}^{-1}\right)$ : L-malic acid in the sample generates $\mathrm{NADH}$, which can be measured spectrophotometrically; tartaric acid $\left(\mathrm{g} \cdot \mathrm{L}^{-1}\right)$ reacts with a vanadium salt $(\mathrm{V})$ in acid medium, generating a coloured complex, which can be quantified spectrophotometrically; potassium (K) $\left(\mathrm{mg} \cdot \mathrm{L}^{-1}\right)$ in the sample consumes NADH (nicotinamide adenine dinucleotide dehydrogenase) by means of a specific reaction catalysed by kinase $\mathrm{K}+$-dependent pyruvate, which can be measured spectrophotometrically; ammonia $\left(\mathrm{mg} \cdot \mathrm{L}^{-1}\right)$ in the sample consumes NADH by means of a reaction catalysed by glutamate dehydrogenase and can be measured spectrophotometrically; PAN (primary amino nitrogen) $\left(\mathrm{mg} \cdot \mathrm{L}^{-1}\right)$ molecules in the sample containing PAN react with o-phthaldialdehyde (OPA) and with a reducing agent in a basic medium, generating a chromogen, which can be measured spectrophotometrically.

\section{Statistical analysis}

Analysis of variance (ANOVA) was used to compare the different parameters according to a general linear model
(GLM), with year as a block factor. Once the typical significant effect of the year on most dependent variables was confirmed, ANOVA was carried out for each dependent variable, with rootstock and virus status as sources of variation for each of the three years. The main effects were determined across both rootstocks, and the effect of virus status in the dependent variables was tested separately for each year in each rootstock, using a t-test. When the symptoms scale was the fixed factor, a Tuckey b-test with $\mathrm{p}<0,05$ was used to separate means after ANOVA. The software used was IBM SPSS Version 24 for Windows.

\section{RESULTS}

The data in Fig. 1 shows the rainfall and Winkler Index and the DSI for the three years. The symptom expression varies for the same plants in the three years and it is significantly higher in plants grafted on 110R (1.95) than on 196.17C (1.59) $(\mathrm{F}=10.2 ; \mathrm{p}>0.002)$. In 2017 (DSI = 2.09), when summer was average in mean temperature but very dry for the region, GLD symptoms were clear in the infected plants. The summer of 2018 was average in rainfall and temperatures and symptoms were mild (DSI $=1.48)$. In 2019, rainfall was average and well distributed during the season, while temperatures were cooler than average during summer and the DSI was 1.74 (Fig. 1).

The general statistical analysis for GLRaV-3 and rootstock is shown in Table 1 . The rootstock influenced mean cluster weight, yield and several parameters of the quality of the must, although TSS was different only in 2017. The effects caused by the virus were highly significant for all variables, except $\mathrm{K}$ and those related to must acidity. Interactions between rootstock and virus were not significant for most variables and mainly affected the nitrogen compounds (PAN and $\mathrm{NH}_{4}$ ). Grape production was dependent on weather conditions, with an average yield in 2017 and 2018, but the bad weather conditions during spring in 2019 were responsible for the irregular and very low yield (Table 2).

The effect of the virus was quite consistent in plants grafted on both rootstocks, but it was higher and more significant for rootstock $110 \mathrm{R}$ than for $196.17 \mathrm{C}$ for most variables. The mean values for both rootstocks and for the three years, along with standard deviations and the results of the statistical analysis, are shown in Table 2. Differences in the main variables due to the virus were significant for 110R not only in 2017 and 2018, but also in 2019. On plants grafted on 196.17C, only 2017 showed differences in the main variables of yield and TSS (total soluble solids).

The data in Figs. 2 and 3 show the percentages of decrease (or increase) in the data according to virus status and for both rootstocks. The decrease in grape weight in the infected plants was maximum in 2017 (42\% for 110R plants) (Fig. 2), and the accumulated yield loss (three years) was $33 \%$, in contrast to the $16 \%$ loss observed for infected 196.17C. The Y (kg)*TSS (Brix) content summarises the effects on both yield and sugar content and provides a good estimate of the total losses: in 2017 the value for infected plants on $110 \mathrm{R}$ was more than $40 \%$ lower than for the healthy ones and two times lower than plants on 196.17C (Fig. 2).

The results concerning the effect of leafroll virus on 


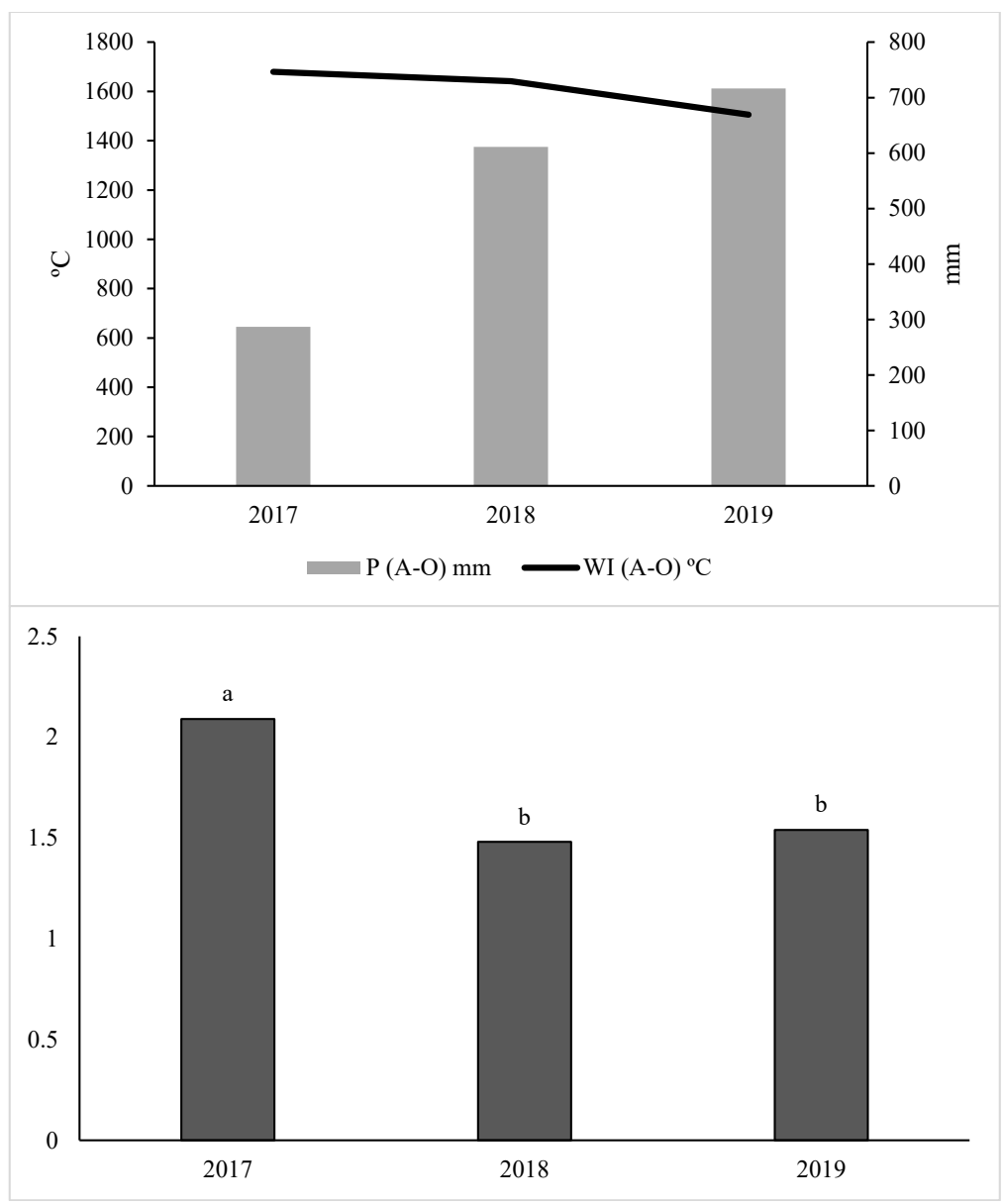

FIGURE 1

Rainfall (L) and Winkler Index $\left({ }^{\circ} \mathrm{C}\right)$ during the growing season (April to October) and DSI from 2017 to 2019. Different letters indicate significant differences between groups $(\mathrm{p}<0.05)$.

must contents are summarised in Table 2 and Fig. 3. The sugar content of the must was always lower in the infected plants, but was affected more consistently in plants on 110R, always with a decrease of more than $10 \%$. The total acidity was usually higher in positive plants on both rootstocks, but was not consistent in all years and was only occasionally significant. The analysis of malic and tartaric acid did not reveal any clear differences, although the malic acid content was higher in positive plants on 196.17C in 2017 and in both rootstocks in 2019. The most important effect was for PAN and ammonia, which were very closely related; the decrease in $196.17 \mathrm{C}$ was $10 \%$ to $20 \%$ in 2017 and 2018 . For $110 \mathrm{R}$, the effect was not only significant, but it was also consistent over the three years, with decreases of up to $45 \%$ and a mean decrease of $35 \%$. Contrasting effects on potassium content were observed in the two plots, although the differences were not significant in either case: the content increased in positive plants growing on $196.17 \mathrm{C}$ and decreased in positive plants growing on 110R.

The severity of GLD symptoms had an effect on the influence of the disease on yield and mean bunch weight and on the quality of the must; Fig. 4 shows the global yield ( $\mathrm{kg} *{ }^{\circ}$ Brix) with GLD symptoms as the independent variable, with all data for both rootstocks and the three years; damage increased with a higher score on the scale from 0 to 3 (Fig. 4).

\section{DISCUSSION}

The detrimental effects of GLD are known to depend on many factors and they increase as the grapevine develops, reaches full production and eventually matures and declines. Montero et al. (2016) suggest that there is a compounding/ accumulating effect of the virus on the vine function, as they found a certain effect of the duration of the virus infection on vine health and grape composition. But damage is related not only to the presence of the virus, but also to the GLD symptoms: plants with more severe symptoms are affected more, but the same plant does not show the same level of symptoms every year. The effect of the disease therefore is variable and unpredictable, and increases the uncertainty. This study shows that in mature Albariño vineyards GLD is associated with increasing failure to supply the winery with regular quantities of grapes with the required sugar content at the optimal harvest date.

GLD appears to be a causal agent of the gradual decrease in crop yield observed throughout the last decade in the vineyard under study, which usually was attributed only to esca and other trunk diseases. The cause was probably 
TABLE 1

Analysis of the GLRaV-3 positive and negative Albariño on rootstocks 196.17C and 110R (2017 to 2019).

\begin{tabular}{|c|c|c|c|c|c|c|c|c|c|c|c|c|c|}
\hline \multirow{2}{*}{ Year } & \multirow{2}{*}{$\begin{array}{l}\text { Source of } \\
\text { Variation }\end{array}$} & \multicolumn{12}{|c|}{ Parameters } \\
\hline & & $\mathrm{df}$ & & $\mathrm{CW}$ & $\mathrm{Yi}$ & TSS & $\mathrm{K}$ & PAN & A & ToA & MA & TA & $\mathrm{pH}$ \\
\hline \multirow{6}{*}{2017} & \multirow{2}{*}{ Rootstock } & \multirow{2}{*}{1} & $\mathrm{~F}$ & 12.9 & 3.35 & 16.8 & 10 & 8.1 & 2.4 & 4.6 & 4.1 & 16.3 & 2.3 \\
\hline & & & $\mathrm{P}<$ & $* * *$ & ns & $* * *$ & $* *$ & $* *$ & ns & $*$ & $*$ & $* * *$ & $\mathrm{~ns}$ \\
\hline & \multirow{2}{*}{ GLRaV-3 } & \multirow{2}{*}{1} & $\mathrm{~F}$ & 97.8 & 25.2 & 42.7 & 0.5 & 15.4 & 26 & 1.1 & 2.3 & 15.6 & 0.04 \\
\hline & & & $\mathrm{P}<$ & $* * *$ & $* * *$ & $* * *$ & ns & $* * *$ & $* * *$ & ns & $\mathrm{ns}$ & $* * *$ & ns \\
\hline & \multirow{2}{*}{$\mathrm{R}^{*} \mathrm{LR}$} & \multirow{2}{*}{1} & $\mathrm{~F}$ & 0.1 & 2.98 & 0.59 & 0.7 & 4.4 & 11 & 1.28 & 4.8 & 0.4 & 6.9 \\
\hline & & & $\mathrm{P}<$ & ns & ns & ns & ns & $*$ & $* *$ & ns & $*$ & $\mathrm{~ns}$ & $*$ \\
\hline \multirow{6}{*}{2018} & \multirow{2}{*}{ Rootstock } & \multirow{2}{*}{1} & $\mathrm{~F}$ & 15.9 & 11.6 & 0.01 & 0.8 & 3.42 & 4.7 & 3.4 & 16 & 1.05 & 2.6 \\
\hline & & & $\mathrm{P}<$ & $* * *$ & $* *$ & ns & ns & $\mathrm{n}$ & $*$ & ns & $* * *$ & $\mathrm{~ns}$ & $\mathrm{~ns}$ \\
\hline & \multirow{2}{*}{ GLRaV-3 } & \multirow{2}{*}{1} & $\mathrm{~F}$ & 18.3 & 7.3 & 18.4 & 0.4 & 14.01 & 19 & 1.6 & 0 & 1.09 & 1.6 \\
\hline & & & $\mathrm{P}<$ & $* * *$ & $* *$ & $* * *$ & ns & $* * *$ & $* * *$ & ns & ns & ns & ns \\
\hline & \multirow{2}{*}{$\mathrm{R} * \mathrm{LR}$} & \multirow{2}{*}{1} & $\mathrm{~F}$ & 8.7 & 1.6 & 3.7 & 0.4 & 0.59 & 0.1 & 0.7 & 0.0 & 0.1 & 2.7 \\
\hline & & & $\mathrm{P}<$ & $* *$ & ns & ns & ns & ns & ns & ns & ns & $\mathrm{ns}$ & ns \\
\hline \multirow{6}{*}{2019} & \multirow{2}{*}{ Rootstock } & \multirow{2}{*}{1} & $\mathrm{~F}$ & 33 & 6.2 & 0.95 & 4.6 & 25.6 & 4.7 & 28.4 & 26 & 20.7 & na \\
\hline & & & $\mathrm{P}<$ & $* * *$ & $*$ & ns & $*$ & $* * *$ & $*$ & $* * *$ & $* * *$ & $* * *$ & \\
\hline & \multirow{2}{*}{ GLRaV-3 } & \multirow{2}{*}{1} & $\mathrm{~F}$ & 1.0 & 0.53 & 16.7 & 0.4 & 3.96 & 19 & 3.24 & 3.8 & 3.6 & na \\
\hline & & & $\mathrm{P}<$ & ns & ns & $* * *$ & ns & $*$ & $* * *$ & ns & $\mathrm{ns}$ & ns & \\
\hline & \multirow{2}{*}{$\mathrm{R} * \mathrm{LR}$} & \multirow{2}{*}{1} & $\mathrm{~F}$ & 10 & 0.04 & 4.97 & 3.9 & 9.9 & 0.1 & 0.16 & 0.0 & 0.1 & na \\
\hline & & & $\mathrm{P}<$ & $* *$ & ns & $*$ & $*$ & $* *$ & ns & ns & ns & ns & \\
\hline
\end{tabular}

LR: leafroll; R: rootstock; df: degrees of freedom; CW: cluster weight (g); Y: yield $\left(\mathrm{kg} \cdot\right.$ plant $\left.^{-1}\right)$; TSS: total soluble solid content $\left({ }^{\circ} \mathrm{Brix}\right)$; K: potassium $\left(\mathrm{mg} \cdot \mathrm{L}^{-1}\right)$; PAN: primary amino nitrogen $\left(\mathrm{mg} \cdot \mathrm{L}^{-1}\right)$; A: ammonium $\left(\mathrm{mg} \cdot \mathrm{L}^{-1}\right)$; ToA: total titratable acidity $\left(\mathrm{g} \cdot \mathrm{L}^{-1}\right)$; $\mathrm{MA}$ : malic acid $\left(\mathrm{g} \cdot \mathrm{L}^{-1}\right)$; TA: tartaric acid $\left(\mathrm{g} \cdot \mathrm{L}^{-1}\right) ; \mathrm{F}$ : Fisher ratio; P: probability; ns: not significant; na: not analysed.

the same for several other plots already uprooted. The influence in the harvest in 2017 due to GLD was greater than at any time since we started working with leafroll viruses in the Albariño cultivar in 1991. Although this occurred to a certain degree on both rootstocks, the negative effects on yield and other indicators of must quality besides the soluble solid content were greater on the $110 \mathrm{R}$ rootstock. Despite the reduced yield, the infected plants grafted on 110R did not improve their sugar content. This confirms the suspicion that arose after a review of the field data from assays conducted in the 1990s and the 2000s (Cabaleiro \& Segura, 1996; Cabaleiro et al., 1999; García-Berrios et al., 2007; Pereira-Crespo et al., 2012). In field evaluations of the performance of the Mencía cultivar, the effect of GLRaV-3 on plants growing on 110R was always very clear; in another field study on the performance of virus-free and LR-infected Mencía on six rootstocks (2008 to 2011), 110R was also the rootstock most consistently associated with decreased production (of up to 50\%) (Pesqueira et al., 2009, and other unpublished data).

It is difficult to compare the effects of GLD on the yield and development in mature plants of grape cultivars grafted on different rootstocks without interference from other viruses (especially if these only have mild effects), and therefore in the literature reviewed the damage could only rarely be attributed only to leafroll disease, even if these were the only symptoms observed. Credi and Babini (1996) detected lower growth in plants growing on 420A, Kobber 5BB and Teleki 5A infected with several combinations of grapevine viruses, including GLRaV-3, but also with grapevine fanleaf and rupestris stem pitting-associated viruses. In addition to the rootstocks (Freedom, Harmony) considered by Golino et al. (2003) in California (USA), other studies involving different combinations of $V$. vinifera and rootstocks report that Couderc1616, Kober 5BB, Teleki 5C, Couderc 3309 and Paulsen 1103 are some of the rootstocks affected the most. Other studies observed that significant effects of virus across all variables measured were highest on $5 \mathrm{BB}$, followed by 3309C, Freedom, 110R, St. George 18 and St. George 15, although the effects were very variable. As far as we are aware, different cultivars may yield different results, because the Mencía cultivar on $1103 \mathrm{P}$ was almost asymptomatic in Galicia (Pesqueira et al., 2009). Golino et al. (2009) reported very variable differences between rootstocks, with combinations of GLRaV causing decreases of between $0 \%$ and $95 \%$ in shoot growth. These researchers also observed that $110 \mathrm{R}$ was the rootstock in which GLRaV-3 most strongly affected plant development.

In most studies of this type, the sugar content is usually affected by leafroll viruses (Charles et al., 2006; Maree et al., 2013), as observed for Albariño, at different ages and particularly for rootstock 110R. In Californian vineyards (USA), the effect of virus treatments on grape composition varied 
TABLE 2

Mean values \pm standard deviation (sd) and significance of the t test for GLRaV-3-positive or -negative plants on rootstocks 196.17C or 110R in 2017, 2018 and 2019.

\begin{tabular}{|c|c|c|c|c|c|c|c|c|c|c|c|c|c|}
\hline & & LR & & CW & $\mathbf{Y}$ & TSS & $\mathbf{K}$ & PAN & $\mathbf{A}$ & ToA & MA & TA & $\overline{\text { pH }}$ \\
\hline \multirow{17}{*}{$196.17 \mathrm{C}$} & \multirow{5}{*}{2017} & \multirow{2}{*}{-} & $\mathrm{m}$ & 184.6 & 12.1 & 23.4 & 2717 & 306.4 & 170 & 10.7 & 5.95 & 6.6 & 3.4 \\
\hline & & & $\pm \mathrm{sd}$ & 20 & 4 & 1.6 & 120.2 & 88 & 35.3 & 1.3 & 0.8 & 0.6 & 0.1 \\
\hline & & \multirow{2}{*}{+} & $\mathrm{m}$ & 139.2 & 9.6 & 21.1 & 2776 & 269.9 & 151 & 11.2 & 7.1 & 6.1 & 3.4 \\
\hline & & & $\pm \mathrm{sd}$ & 16.5 & 3.9 & 1.5 & 166.9 & 64.2 & 40.4 & 1.6 & 1.1 & 0.5 & 0.1 \\
\hline & & & & $* * *$ & $* * *$ & $* * *$ & $\mathrm{~ns}$ & $\mathrm{~ns}$ & $\mathrm{~ns}$ & $\mathrm{~ns}$ & $* *$ & $*$ & $\mathrm{~ns}$ \\
\hline & \multirow{5}{*}{2018} & \multirow{2}{*}{ - } & $\mathrm{m}$ & 170.4 & 14.5 & 21.3 & 1961 & 297.1 & 185 & 12.1 & 6.9 & 5.3 & 3.3 \\
\hline & & & $\pm \mathrm{sd}$ & 28.1 & 6.1 & 1.8 & 584.6 & 96.4 & 43.9 & 1.1 & 1.1 & 0.7 & 0.1 \\
\hline & & \multirow{2}{*}{+} & $\mathrm{m}$ & 165.6 & 12.2 & 20.2 & 1969 & 238.4 & 142 & 11.8 & 7 & 5 & 3.3 \\
\hline & & & $\pm \mathrm{sd}$ & 36.2 & 4.4 & 1.4 & 547.4 & 53.8 & 31.8 & 1.6 & 1.4 & 0.8 & 0.1 \\
\hline & & & & ns & ns & $*$ & ns & $*$ & $* *$ & $\mathrm{~ns}$ & ns & ns & $\mathrm{ns}$ \\
\hline & \multirow{7}{*}{2019} & \multirow{2}{*}{-} & $\mathrm{m}$ & 97.8 & 3.4 & 21 & 2606 & 336.1 & 191 & 13 & 7,8 & 6,1 & na \\
\hline & & & $\pm \mathrm{sd}$ & 29.7 & 1.9 & 1.4 & 1104.5 & 82.9 & 54.8 & 1.4 & 1.8 & 0.5 & \\
\hline & & \multirow{2}{*}{+} & $\mathrm{m}$ & 68.7 & 2.8 & 20.1 & 2901 & 361.1 & 200 & 13.8 & 8.6 & 5.7 & na \\
\hline & & & $\pm \mathrm{sd}$ & 20.6 & 2.2 & 1.6 & 720.4 & 100.5 & 42.4 & 1.7 & 1.7 & 0.9 & \\
\hline & & & & $* *$ & $\mathrm{~ns}$ & ns & ns & ns & ns & ns & ns & ns & \\
\hline & & - & $\mathrm{m} 3 \mathrm{y}$ & 177.5 & 10.0 & 21.9 & 2427.9 & 313.2 & 181.8 & 11.9 & 6.9 & 6.0 & 3.3 \\
\hline & & + & m3y & 152.4 & 8.2 & 20.5 & 2548.4 & 289.8 & 164.5 & 12.3 & 7.6 & 5.6 & 3.4 \\
\hline \multirow{17}{*}{ 110R } & \multirow{5}{*}{2017} & \multirow{2}{*}{-} & $\mathrm{m}$ & 169.2 & 12 & 22.2 & 2629 & 291.5 & 188 & 11.2 & 6 & 7.3 & 3.5 \\
\hline & & & $\pm \mathrm{sd}$ & 35.4 & 4.3 & 2.1 & 146.7 & 87.9 & 41.8 & 1.2 & 1.2 & 0.7 & 0.1 \\
\hline & & \multirow{2}{*}{+} & $\mathrm{m}$ & 120.2 & 6.9 & 19.6 & 2625 & 171.9 & 101 & 11.6 & 5.8 & 6.6 & 3.4 \\
\hline & & & $\pm \mathrm{sd}$ & 23.6 & 3.2 & 1.9 & 118.8 & 45.8 & 33.7 & 1.8 & 1.2 & 0.3 & 0.1 \\
\hline & & & & $* * *$ & $* * *$ & $* * *$ & ns & $* * *$ & $* * *$ & ns & $\mathrm{ns}$ & $*$ & $\mathrm{~ns}$ \\
\hline & & \multirow{2}{*}{ - } & $\mathrm{m}$ & 180.6 & 12.9 & 22.4 & 2213.0 & 275.8 & 165 & 11.4 & 5.8 & 5.5 & 3.4 \\
\hline & & & $\pm \mathrm{sd}$ & 32.30 & 5.9 & 1.2 & 330.4 & 46.4 & 30.3 & 0.4 & 0.7 & 0.5 & 0.1 \\
\hline & 2018 & \multirow{2}{*}{+} & $\mathrm{m}$ & 126.4 & 10.1 & 19.3 & 2021.5 & 186.8 & 117.4 & 11.4 & 5.8 & 5.3 & 3.3 \\
\hline & & & $\pm \mathrm{sd}$ & 22.30 & 3.4 & 1.7 & 572.1 & 66 & 38.3 & 1.1 & 0.6 & 0.95 & 0.1 \\
\hline & & & & $* * *$ & $*$ & $* * *$ & $\mathrm{~ns}$ & $* *$ & $* *$ & $\mathrm{~ns}$ & $\mathrm{~ns}$ & $\mathrm{~ns}$ & $\mathrm{~ns}$ \\
\hline & \multirow{7}{*}{2019} & \multirow{2}{*}{-} & $\mathrm{m}$ & 127.4 & 4.9 & 22.4 & 2588.5 & 295 & 165 & 11.2 & 5.8 & 6.9 & na \\
\hline & & & $\pm \mathrm{sd}$ & 29.9 & 2.7 & 1.6 & 126.5 & 62.1 & 36.7 & 0.7 & 0.8 & 0.6 & \\
\hline & & \multirow{2}{*}{+} & $\mathrm{m}$ & 89.9 & 4.5 & 19.6 & 2438.6 & 184.5 & 109.8 & 11.7 & 6.5 & 6.6 & na \\
\hline & & & $\pm \mathrm{sd}$ & 13.7 & 2.6 & 1.8 & 121.0 & 45.3 & 26.6 & 1.0 & 1.1 & 0.7 & \\
\hline & & & & $* * *$ & $\mathrm{~ns}$ & $* *$ & $* *$ & $* * *$ & $* * *$ & $\mathrm{~ns}$ & $\mathrm{~ns}$ & $\mathrm{~ns}$ & \\
\hline & & - & $\mathrm{m} 3 \mathrm{y}$ & 159.1 & 9.9 & 22.3 & 2476.9 & 287.4 & 172.6 & 11.3 & 5.9 & 6.6 & 3.5 \\
\hline & & + & $\mathrm{m} 3 \mathrm{y}$ & 99.1 & 7.2 & 19.5 & 2361.6 & 181.1 & 109.3 & 11.6 & 6.0 & 6.2 & 3.4 \\
\hline
\end{tabular}

m: mean; m3y: mean 3 years; sd: standard deviation; CW: cluster weight $(\mathrm{g})$; Y: yield $(\mathrm{kg} \cdot \mathrm{plant})$; TSS: total soluble solid content $\left({ }^{\circ} \mathrm{Brix}\right)$; $\mathrm{K}$ : potassium $\left(\mathrm{mg} \cdot \mathrm{L}^{-1}\right)$; PAN: primary amino nitrogen $\left(\mathrm{mg} \cdot \mathrm{L}^{-1}\right)$; A: ammonium $\left(\mathrm{mg} \cdot \mathrm{L}^{-1}\right)$; ToA: total titratable acidity $\left(\mathrm{g} \cdot \mathrm{L}^{-1}\right)$; MA: malic acid $\left(\mathrm{g} \cdot \mathrm{L}^{-1}\right)$; TA: tartaric acid $\left(\mathrm{g} \cdot \mathrm{L}^{-1}\right)$; na: not analysed; * significant at $\mathrm{P}<0.05 ; * *$ significant at $\mathrm{P}<0.01 ; * * *$ significant at $\mathrm{P}<0.001$; ns: $\mathrm{P}>$ 0.05 not significant.

greatly among isolates and depended on rootstock, but a reduction in the sugar content in the must from Cabernet Sauvignon plants infected with GLRaV-3, alone or in combination with GLRaV-2 and grapevine fleck virus, was observed for all rootstocks (Rowhani et al., 2015). No changes in total acidity were observed by Golino et al. (2009) in the first har- vests, as in the present study, with no consistent increase in the total acidity of the must. The high total acidity of the Albariño must (Table 2) is characteristic of the cultivar, and was not clearly affected in either the young or mature vineyards in any of our previous studies (Cabaleiro \& Segura, 1996; Cabaleiro et al., 1999). 


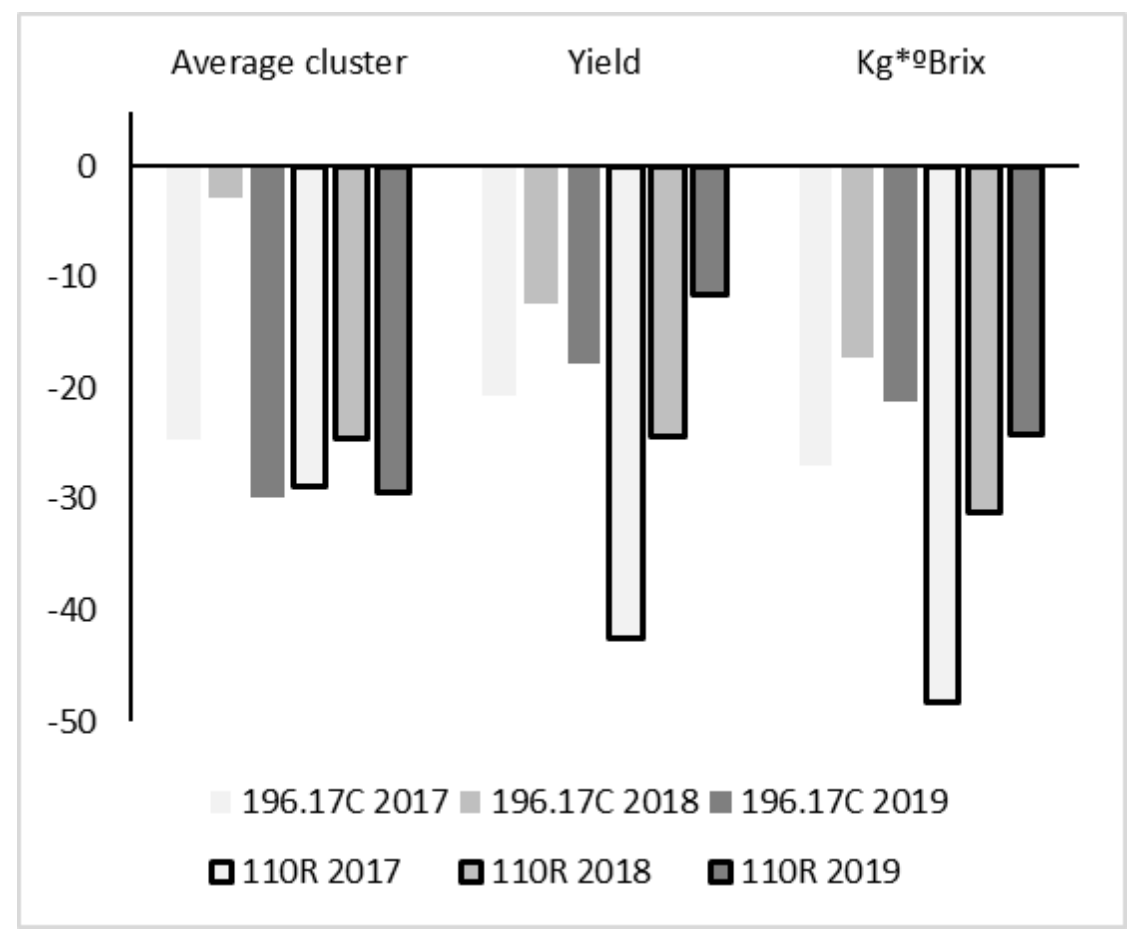

FIGURE 2

Percentage of decrease (relative to leafroll-free plants) in cluster weight, yield and Y*TSS (yield x total soluble solid content) in LR-infected plants on 196.17C and 110R rootstock in 2017, 2018 and 2019.

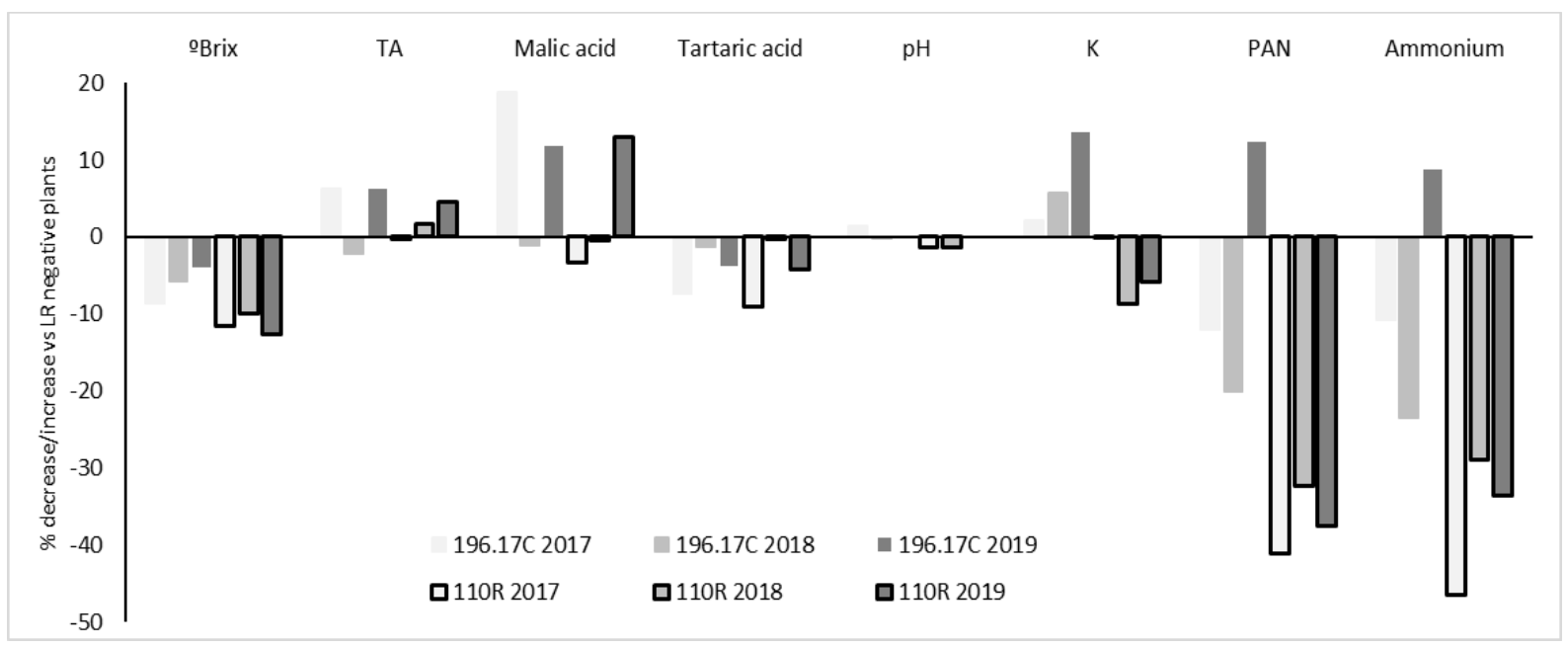

FIGURE 3

Quality of the must from 2017 to 2019. Percentage of decrease or increase in the variables considered in the LR-infected plants grafted onto $196.17 \mathrm{C}$ or $110 \mathrm{R}$ with respect to the must components of the LR-free plants.

Kliewer and Lider (1976) reported that GLD increases the potassium content of Burger grapes and that it induces higher levels of organic substances that interfere with grape ripening. Although potassium content is often not reported, it is not always higher in infected plants. GLRaV induced an increase in the potassium content of the must from Mencía grafted onto 110R (Pesqueira et al., 2009), as previously observed in Sultana (Hale \& Woodham, 1979). Most of the recent studies do not mention nitrogen compounds. We de- tected lower levels of PAN and ammonium in the infected plants, and the decrease was more significant in 110R (more than $40 \%$ ) than in $196.17 \mathrm{C}$. A reliable source of nitrogen is important for the fermentation of must and this decrease may be problematic; the minimum PAN recommended by oenologists $\left(150 \mathrm{mg} \cdot \mathrm{L}^{-1}\right)$ was reached both in healthy and LR-infected Albariño cultivars in the present study, but $250 \mathrm{mg} \cdot \mathrm{L}^{-1}$ is preferable and $400 \mathrm{mg} \cdot \mathrm{L}^{-1}$ improves aroma (Vilanova et al., 2012). 


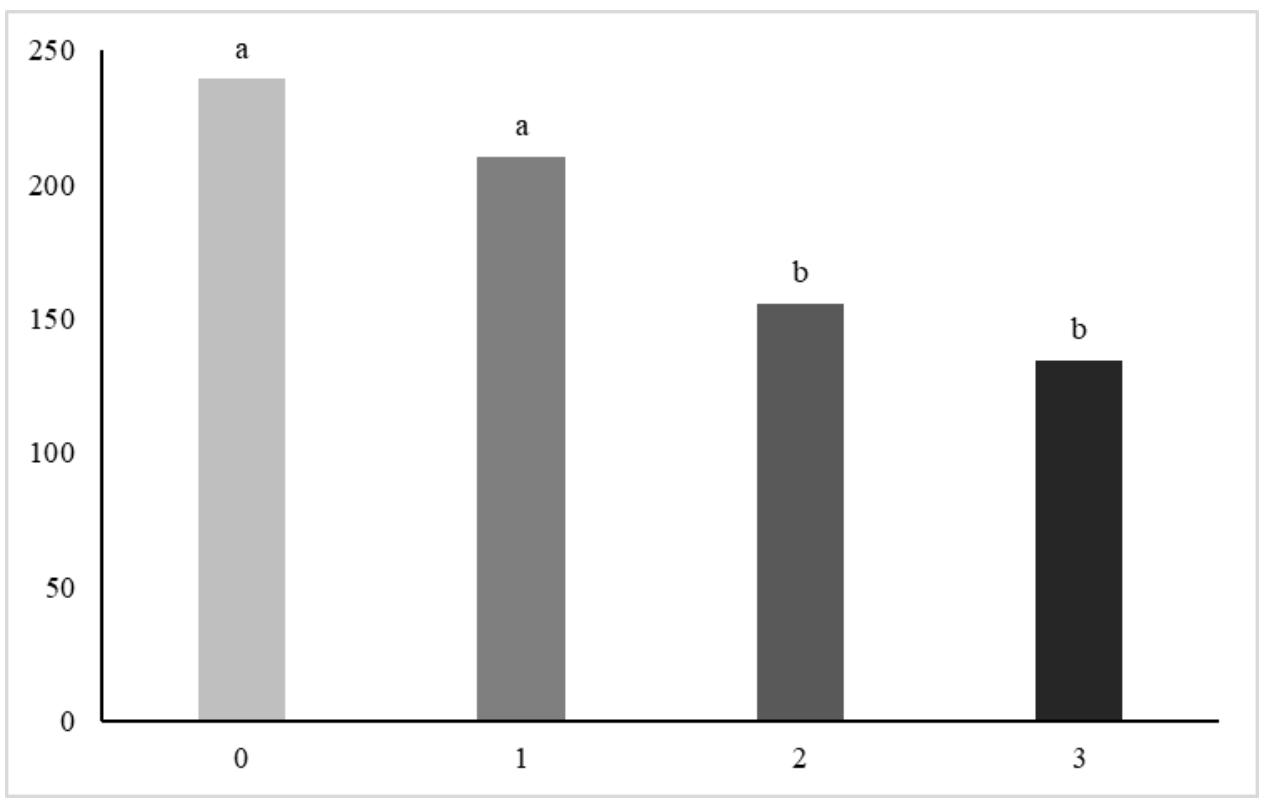

FIGURE 4

Index of global yield: Yield (kg) x Total soluble solid content (TSS ${ }^{\circ}$ Brix) according to GLD symptoms (0 to 3$)$ of all plants from 2017 to 2019. Different letters indicate significant differences between groups $(\mathrm{p}<0.05)$.

The age of the vineyard should be taken into account, as growers claim that GLD shortens the longevity of the plants (Atallah et al., 2012). The medium- to long-term decline is better documented as "grapevine degeneration" caused by nepoviruses (Andret-Link et al., 2004) than by GLD. We did not observe any differences in the yield of the young GLDinfected plants grafted onto 196.17C and SO4 (Cabaleiro et al., 1999), and again only the sugar content was affected in the harvests from 2002 to 2005 in a younger than 10-year-old vineyard with Albariño on 196.17C (García-Berrios et al., 2007). However, grapes from a 12 -year-old vineyard grafted onto 110R rootstock not only had a lower sugar content, but the fruit weight was reduced (Cabaleiro \& Segura, 1996). The present data show an important effect of GLRaV-3 on the sugar content of the must, but also on the yield of adult Albariño plants that had been chosen for their similar vigour and development, suggesting that the economic impact of GLD may be higher than originally estimated (Cabaleiro et al., 2013).

Grapevine leafroll disease is fairly prevalent in Galician vineyards due to the use of "standard" plant material (Segura et al., 1993), as certified virus-free stock of the traditional cultivars was not available until recently. We have observed that the spread of P. ficus in the Rías Baixas is altering the situation (Vilas, 2021). Thus, although the incidence of GLRaV infection in the red traditional cultivars grown inland has not varied significantly over the last few decades and is only very rarely higher than 40\% (Pesqueira et al., 2009), more than $80 \%$ of the plants in many vineyards in the south of Galicia are infected. Leafroll symptoms that could alarm the growers, as happens in red cultivars, are not so easy to observe in the canopy under the traditional horizontal trellis still common for Albariño. The fact that GLRaV-3 is the most common GLRaV, and often the only among the three main
LR viruses, indicates that the mealybug is an active vector at low populations. $\mathrm{Pl}$. ficus was an unknown or rare pest in the last decade of the $20^{\text {th }}$ century in Galicia, and some wineries only recently started to use control techniques to prevent the transmission of GLRaV-3 to virus-free plants (Vilas, 2020), as has been done in other countries (Bell et al., 2021). These techniques include mating disruption as an alternative to occasional insecticide spraying, screening of GLRaV-3 by quick and cheap detection methods (tissue-printing ELISA), and roughing of infected plants during the first years of the plantation.

Although many rootstocks are authorised for use in Spain, in practice the choice is limited by the availability of material in the local nurseries. Most rootstocks sold in Spain are selected for the conditions that predominate in Mediterranean viticulture. In Galicia, the soils are acid, organic and sandy, and the summers are cool with moderate drought relative to the Mediterranean region. These conditions, together with the fact that Albariño is a vigorous cultivar, make 196.17C a suitable rootstock a priori. However, some wineries from other regions of Spain began planting vineyards in Galicia in the 1980s, with some also using the 110R rootstock for Albariño. Indeed, 110R is already the dominant rootstock used with the Mencía cultivar in the grape-growing areas in the previously mentioned studies (Pesqueira et al., 2009).

The $110 \mathrm{R}$ rootstock is the most commonly used in Spain (in $50 \%$ to $70 \%$ of the vineyards), and for all kinds of cultivars in all wine-growing regions (Ignacio Provedo, Viveros Provedo, personal communication). Nurseries usually provide general information about the resistance of rootstocks to some soil fungi and nematodes and to phylloxera, but not about resistance to viruses. However, Grant (2016) recommends avoiding the 3309C, Freedom and $5 \mathrm{BB}$ rootstocks unless the cultivars are guaranteed to be 
virus free. In the case of $110 \mathrm{R}$, information about particular susceptibility to GLD would be useful if it is to be planted in areas where GLRaV-3 vectors are widely spread, as in the south of Galicia and in many of the Mediterranean grape-growing regions in Spain, Italy and France, as well as in California, where this rootstock is also used (Domingo Salazar, Comité International de la Pépinière, personal communication).

\section{CONCLUSIONS}

The effect of GLRaV-3 on mature plants of Albariño is significant and contributes to shortening the lifespan of a vineyard, leading to earlier than scheduled uprooting. Owing to the huge number of rootstocks, and the even greater number of cultivars used in viticulture throughout the world, it is difficult to provide general recommendations, other than to prevent the viruses from infecting virus-free plant material by detecting and controlling the vectors in the field, along with uprooting the infected plants, as soon as possible. In sensitive varieties such as Albariño, especially in areas with an active spread of mealybugs, grafting on 196.17C seems to be safer in the medium to long term, although other rootstock-scion-GLRaV combinations should be tested.

\section{LITERATURE CITED}

Almeida, R., Daane, K., Bell, V., Blaisdell, G.K., Cooper, M., Herrbach, E. \& Pietersen, G., 2013. Ecology and management of grapevine leafroll disease. Front. Microbiol. 4, 94.

Andret-Link, P., Laporte, C., Valat, L., Ritzenthaler, C., Demangeat, G., Vigne, E., Laval, V., Pfeiffer, P. Stussi-Garaud, C. \& Fuchs, M., 2004 Grapevine fanleaf virus: Still a major threat to the grapevine industry. J. Plant Pathol. 86(3), 183-195.

Atallah, S.S., Gómez, M.I., Fuchs, M.F. \& Martinson, T.E., 2012. Economic impact of grapevine leafroll disease on Vitis vinifera cv. Cabernet franc in Finger Lakes vineyards of New York. Am. J. Enol. Vitic. 63(1), 73-79.

Bell, V.A., Lester, P.J., Pietersen, G. \& Hall, A.J., 2021. The management and financial implications of variable responses to grapevine leafroll disease. J. Plant Pathol.103, 5-15.

Borgo, M., Bertazzon, N., Anaclerio, F. \& Angelini, E., 2006. Graft incompatibility and leafroll symptoms in grapevines affected by different GLRaV-2 variants. In: Proc. $15^{\text {th }}$ Meeting ICVG, April, 2006, Stellenbosch, South Africa. pp. $25-27$.

Cabaleiro, C. \& Segura, A., 1996. Efecto del enrollado de la vid (GLRaV-3) en un viñedo en plena producción del cultivar "Albariño". INIA, Prod. y Prot.-Veg. 11(3), 451-463.

Cabaleiro, C., Couceiro, C., Pereira, S., Cid, M., Barrasa, M. \& Segura, A., 2008. Spatial analysis of epidemics of grapevine leafroll associated virus-3. Eur. J. Plant Pathol. 121(2), 121-130.

Cabaleiro, C., Pesqueira, A.M., Barrasa, M. \& García-Berrios, J.J., 2013. Analysis of the losses due to grapevine leafroll disease in Albariño vineyards in Rías Baixas (Spain). Cienc. Tec. Vitivinic. 28(2), 43-50.

Cabaleiro, C., Segura, A. \& García-Berrios, J.J., 1999. Effects of grapevine leafroll-associated virus 3 on the physiology and must of Vitis vinifera $\mathrm{L}$. cv. Albarino following contamination in the field. Am. J. Enol. Vitic. 50(1), 40-44.

Charles, J.G., Cohen, D., Walker, J.T.S., Forgie, S.A., Bell, V.A. \& Breen, K.C., 2006. A review of grapevine leafroll associated virus type 3 (GLRaV-3) for the New Zealand wine industry. Hort. Research Client Report, 18447.
Cid, M., Cabaleiro, C. \& Segura, A., 2003. Detection of grapevine leafrollassociated virus 3 in rootstocks. In: Proc. $14^{\text {th }}$ Meeting ICVG, September 2003, Locorotondo-Bari, Italy. pp. $41-42$.

Credi, R. \& Babini, A.R., 1996. Effect of virus and virus-like infections on the growth of grapevine rootstocks. Adv. Hort. Sci. 10, 95-98.

Dry, N., 2007. Grapevine rootstocks: Selection and management for South Australian vineyards. Lythrum Press, Adelaide.

Freeborough, M.J. \& Burger, J.T., 2008. Leafroll: Economic implications. Wynboer, A Technical Guide for Wine Producers. Available from http://www.wynboer.co.za/recentarticles/200812-leafroll.php3 (accessed ??).

Fuller, K.B., Alston, J.M. \& Golino, D.A., 2019. Economic benefits from virus screening: A case study of grapevine leafroll in the North Coast of California. Am. J. Enol. Vitic. 70(2), 139-146.

García-Berrios, J.J., Pereira, S., Enríquez, M., Segura, A. \& Cabaleiro, C., 2007. Climatic change and effects of the leafroll viruses on the must characteristics of the cv Albariño. Proc. CONCLIVIT, April 2007, Zaragoza. pp. $123-128$.

Golino, D.A., 1993. Potential interactions between rootstocks and grapevine latent viruses. Am. J. Enol. Vitic. 44(2), 148-152.

Golino, D., Sim, S. \& Rowhani, A., 2000. Identification of the latent viruses associated with young vine decline in California. In: Proc $13^{\text {th }}$ Meeting ICVG, March 2000, Adelaide, Australia. pp. 85 - 86.

Golino, D.A., Sim, S. \& Rowhani, A., 2003. The role of rootstock genotype in the effects of single and mixed infections of grapevine viruses. In: Proc. $14^{\text {th }}$ Meeting of ICVG, September 3003, Locorotondo-Bari, Italy. pp. 246 $-247$

Golino, D.A., Wolpert, J., Sim, B.J. \& Aderson, R.A., 2008. Virus effects on vine growth and fruit components of Cabernet Sauvignon on six rootstocks. In: Proc. $2^{\text {nd }}$ Ann. Nat. Vitic. Res. Conf., July 2008, University of California, Davis. pp. $28-29$.

Grant, S, 2016. Selecting a rootstock for a wine grape vineyard. Progressive Viticulture. Available from https://www.progressivevit.com/selecting-arootstock-for-a-wine-grape-vineyard/

Greif, C., Garau, R., Boscia, D., Prota, V.A., Fiori, M., Bass, P., Walter, B. \& Prota, U., 1995. The relationship of grapevine leafrollassociated closterovirus 2 with a graft incompatibility condition of grapevines. Phytopath. Medit. 34(3), 167-173.

Hale, C.R. \& Woodham, R.C., 1979. Effect of grapevine leafroll disease on the acid and potassium composition of Sultana grapes. Am. J. Enol. Vitic. 30(2), 91-92.

Kliewer, W.M. \& Lider, L.A., 1976. Influence of leafroll virus on composition of Burger fruits. Am. J. Enol. Vitic. 27(3), 118-124.

Komar, V., Vigne, E., Demangeat, G., Lemaire, O., \& Fuchs, M., 2010. Comparative performance of virus-infected Vitis vinifera $\mathrm{cv}$. Savagnin rose grafted onto three rootstocks. Am. J. Enol. Vitic. 61(1), 68-73.

Krake, L.R., 1993. Characterization of grapevine leafroll disease by symptomatology. Aust. \& N. Z. Wine Ind. J. 8(1), 40-44.

Maree, H.J., Almeida, R.P.P., Bester, R., Chooi, K.M., Cohen, D., Dolja, V.V., Fuchs, M.F., Golino, D.A., Jooste, A.E.C., Martelli, G.P., Naidu, R.A., Rowhani, A., Saldarelli, P. \& Burger, J.T., 2013. Grapevine leafrollassociated virus 3. Front. Microbiol. 4, 82-93.

Montero, M. Pérez-Bueno, M.L., Barón, M., Florez-Serasa, I., Tohge, T., Fernie, A.R., El Aou Ouad, H., Flexas, J., Bota, J., 2016. Alterations in primary and secondary metabolism in Vitis vinifera "Malvasía de banyalbufar" upon infection with Grapevine leafroll-associated virus 3 . Physiol. Plant. 157(4), 442-452. 
Naidu, R., Rowhani, A., Fuchs, M., Golino, D. \& Martelli, G.P., 2014 Grapevine leafroll: A complex viral disease affecting a high-value fruit crop. Plant Dis. 98(9), 1172-1185.

Naidu, R.A., Maree, H.J. \& Burger, J.T., 2015. Grapevine leafroll disease and associated viruses: A unique pathosystem. Ann. Rev. Phytopathol. 53, 613-634.

Pereira-Crespo, S., Segura, A., García-Berrios, J. \& Cabaleiro, C., 2012. Partial defoliation improves must quality of cv. Albariño infected by grapevine leafroll associated virus 3. Phytopathol. Medit. 51(2), 383-389.

Pesqueira, A.M., González, R. \& Cabaleiro, C., 2009. Grapevine leafroll disease in Vitis vinifera cv Mencía. In: Proc. $16^{\text {th }}$ Meeting of ICVG, August/ September 2009, Dijon, France. pp. 318 - 319.

Pesqueira, A.M., Vieito, C., García-Berrios, J.J. \& Cabaleiro, C., 2018. Digital image analysis of leafroll symptoms and damage assessment for different GLRaV-3 isolates. In: Proc. 19 ${ }^{\text {th }}$ Meeting ICVG, April 2018, Santiago de Chile. pp. 136 - 137.

Ricketts, K.D., Gomez, M.I., Atallah, S.S., Fuchs, M.F., Martinson, T.E., Battany, M.C., Bettiga, L.J., Cooper, M.L., Verdegaal, P.S. \& Smith, R.J., 2015. Reducing the economic impact of grapevine leafroll disease in California: Identifying optimal disease management strategies. Am. J. Enol. Vitic. 66(2), 138-147.
Rowhani, A., Golino, D.A., Klaassen, V., Sim, S.T., Gouran, M. \& Al Rwahnih, M., 2015. Grapevine leafroll associated virus 3: Effects on rootstocks, vine performance, yield and berries. In: Proc. $18^{\text {th }}$ Meeting ICVG, September 2015, Ankara, Turkey. pp. 161 - 162.

Uyemoto, J., Rowhani, A., Luvisi, D. \& Krag, C., 2001. New closterovirus in 'Redglobe' grape causes decline of grafted plants. Calif. Agric. 55(4), 28-31

Vilanova, M., Siebert, T.E., Varela, C., Pretorius, I.S. \& Henschke, P.A., 2012. Effect of ammonium nitrogen supplementation of grape juice on wine volatiles and non-volatiles composition of the aromatic grape variety Albariño. Food Chem. 133(1), 124-131.

Vilas, R. 2020. Monitoring and control of Planococcus ficus Sig (Hemiptera: pseudococcidae) in a vineyard of cv "Albariño" in the appellation Rías Baixas in O Rosal: Study of the epidemiological determinants (in Spanish). Master's thesis, University of Santiago de Compostela, Spain.

Volpe, M. L., Talquenca, S.G., Engel, E.A. \& Gracia, O., 2010. Incidence of grapevine leafroll associated viruses-1, -2, and -3 in Mendoza vineyards. Trop. Plant Pathol. 35(6), 377-380. 